\title{
The Model Development of Authentic Assessment Instrument Used Google Classroom in Learning Band Music
}

\author{
Irwan $^{1}$, Syafri Anwar ${ }^{2}$, Atmazaki $^{3}$, Agusti Efi ${ }^{4}$ \\ ${ }^{1}$ Postgraduate Program, Universitas Negeri Padang, Indonesia \\ *irwanmenan29@gmail.com
}

\begin{abstract}
The reason music learning assessment instruments need to be developed is so that the expected learning outcomes can be achieved in increasing knowledge, attitudes and musical arts skills based on authentic. If the music learning assessment instrument is right on target in seeing students 'competencies, the level of quality of students' abilities will be achieved in accordance with the expected learning outcomes. Google classroom is one of solutions of Authentic Assessement Instrumen in Learning Band Music. This research is a development study and uses the development of the ADDIE model. ADDIE model was chosen because this model is suitable to be applied in learning in schools. The results of the product development of the Authentic Assessment Instrument Model in Band Music Learning have a score of 78.82 and are classified as valid. The practicality of the authentic assessment instruments in learning band music is 81.56 and is classified as very practical. The effectiveness of authentic assessment instruments in learning band music is 82.1 and is classified as very effective.
\end{abstract}

Abstract: ADDIE Model; Google Classroom; Online Learning;

\section{Introduction}

This pandemic era it is not possible to always face to face in learning. At present, the art music education has not been able to fully facilitate educational goals. Based on preliminary observations in August 2020, it is known that the evaluation of music art learning has not been carried out effectively by the teacher. Most music art teachers do not carry out learning evaluations in accordance with existing procedures. There are no specific guidelines in carrying out assessment of music art learning. Research that has been carried out in various countries relating to evaluation evaluation generally states that the development of assessment rubric tests greatly improves the quality of learning. Authentic assessment gives a significant impact on the creativity of students. The results of authentic assessment give a picture that students have freedom in making and playing musical compositions. In this regard, it is necessary to develop an instrument model for music learning assessment based on authentic that is able to measure the level of learning success undertaken by teachers comprehensively. 
In addition, the assessment instrument model can also be used as a teacher's accountability to parents or guardians of students, stakeholders, government and the community regarding learning that has been carried out. Some music educators believe that music teaching and learning are very difficult, if not impossible, to assess [2].

\section{Methodology}

This research method is classified as Development Research and uses the ADDIE Development Model. The ADDIE steps in this research are;

1.1. The analysis in this stage focuses on the strengths and weaknesses of the instruments, goals, objectives and relevant resources in developing authentic assessment instruments for band music learning.

1.2. The design in this stage is focused on the teacher's needs regarding authentic instruments as well as designing authentic instruments in learning Band Music.

1.3. Development of the initial draft product book authentic assessment model and authentic assessment model in learning Band Music.

1.4. Implementation is a trial step for developing an Authentic Assessment model in learning Music Bands.

1.5. Evaluation is to find out the quality of the product development model of Authentic Assessment in learning Music Band.

\section{Result and Discussion}

\subsection{Product Validation Results}

The validation of authentic assessment instruments in band music learning aims to find out the validity that is implemented in research, the authentic instrument in band music learning consists of content worthiness, graphics and language from the results of five validators concluding that authentic instrument in band music learning is very valid. Then the ICC (Intraclass Correlation Coefficient) value of the authentic assessment instrument in the learning of band music is calculated using spps 22 .

Table 1. Results of The Interclass Correlation Coefficient Validation of Authentic Instrument Assessment in Learning Music Band

\begin{tabular}{lccc}
\hline \multicolumn{1}{c}{ Product } & $\begin{array}{c}\text { Number of } \\
\text { Validators }\end{array}$ & $\begin{array}{c}\text { Interne } \\
\text { Correlation } \\
\text { Cofecition }\end{array}$ & Category \\
\hline The performance & 5 & 76.7 & Valid \\
Project & 5 & 81.9 & Very Valid \\
Fortopolio & 5 & 86.2 & Very Valid \\
Article & 5 & 74.8 & Valid \\
Product & 5 & 74.5 & Valid \\
Average & 5 & 78.82 & Valid \\
\hline
\end{tabular}

Note: the assessments form collected to google classroom. 
Based on the SPSS calculation results in Table 1 above, it is known that the product development of authentic assessment instruments in learning Music Bands has an ICC score of 78.82 and considered valid.

The validation results show that the instrument developed was appropriate and referred to the band music curriculum or material based on SK / KD. The final form of authentic assessment instruments in the band's music learning are; (1) performance assessment format, (2) project assessment in the form of assessment format, (3) written assessment in the form of objective questions and content, (4) portofolio assessment in the form of a questionnaire filled out by students to assess themselves and their existence student assessments by friends. [7] described that good judgment has a positive impact on the achievement of objectives. The products that have been developed are performance assessment, project, written, and portfolio that have been developed in accordance with the stages of the ADDIE model steps.

The results of the validation and reliability of this authentic assessment instrument product are very valid. This product also presents the stages of students observing, asking questions, practicing, carrying out tasks that students must do. In addition, the product content is in accordance with KI, KD, indicators, objectives, and student needs. The contents of this product do not conflict with moral values but develop creativity. While in language, language must be specified with band music. Language is easy to understand and does not use long sentences and the choice of words used is right, consistency, and needs to be adjusted to EYD. In addition, the sentences used are clear and do not cause multiple meanings. While in graphics, the type of letters used are precise, consistent, and easy to read. Good size, color, the use of uppercase and lowercase letters is appropriate and appropriate. The display design was passed with three revisions.

The validity of the instrument is due to meeting the components that have been delivered by the expert. The data means that all validators say that the authentic assessment instrument in the band's music learning is worth using. A product that should be able to help the assessment system in learning. assessment not only lies in the knowledge of students, but also lies in the skills or skills of students. Therefore, learning assessment must be in accordance with the concepts that already exist in the research findings. Another reason that makes a model valid is the product builder variable. In this study the product was built by rational thinking the need for authentic assessment instruments in band music learning, goals, and usability, development procedures, as well as the language used and the presentation of the assessment instruments to assess band music according to what [1] found, educational evaluation (1) authentic assessment or work-based assessment (2) assessment by students (3) project evaluation (4) self-assessment or self evaluation. Then writing about the assessment in the book [9] states that the assessment consists of (1) measurement, (2) assessment or assessment, (3) tests and (4) evaluation.

From the three assessment developments above, it can be concluded that the authentic instrument is expected to be able to guide teachers in conducting the assessment based on the components that have been determined. Therefore, authentic valuation instruments include, rational, valuation definitions, indicators of valuation instruments, assessment systems include philosophical and theoretical. So the validity of authentic instruments in the band's music learning is the consistency between the grading system and the form of assessment that has been set in the school in accordance with the expectations When a product is developed based on its components, the product will become valid. When the product can be used by a teacher or instructor, books are practical, when the product helps users reach the expected knowledge and skills, the product is effective. 
Data analysis on the validation of authentic assessment instruments in the band's music learning consisted of five results of the validation. First, the results of the performance evaluation validation are 76.7. This shows that the performance assessment instrument is valid. Secondly, the result of project valuation validation is 81.9 . This shows that the project assessment instrument is very valid. Third, the result of written evaluation validation is 74.8 . This shows that the written assessment instrument is valid. Fourth, the result of portfolio valuation validation is 86.2 . This shows that the product valuation instrument is very valid. Fifth, the product validation results are 74.5. This shows that the product valuation instrument is valid.

\subsection{Product Practicality Results}

Practice test with five components namely; performance assessment, project assessment, portfolio assessment, written assessment, and product assessment.

Table 2. Results of The Interclass Correlation Coefficient Practicality of Authentic Assessment Instruments in Learning Band Music

\begin{tabular}{lccc}
\hline \multicolumn{1}{c}{ Product } & $\begin{array}{c}\text { Total number } \\
\text { of teachers }\end{array}$ & $\begin{array}{c}\text { Interne Correlation } \\
\text { Cofecition }\end{array}$ & Category \\
\hline The performance & 5 & 81.2 & Very practical \\
Project & 5 & 78.4 & Practical \\
Fortopolio & 5 & 80.8 & Very practical \\
Article & 5 & 82.3 & Very practical \\
Product & 5 & 85.1 & Very practical \\
Average & 5 & 81.56 & Very practical \\
\hline
\end{tabular}

Note: the assessments form collected to google classroom.

Based on the SPSS calculation results in Table 2 above, it is known that the product development of authentic assessment instruments in learning Music Bands has an ICC score of 81.56 and is classified as very practical.

Based on the results of the practicality of authentic assessment instruments in learning band music shows that it is very practical and easy to understand by the teacher. Based on the data of practicality test results in the statement of practicality instruments get average value with a percentage of 81.56 and categorized as very practical. the ICC value (agreement between rater assessments) obtained for the overall (Average Measures) results indicate that from all rater ratings are in the very practical category, namely 81.56 or $81.46 \%$.

\subsection{Product Effectiveness Results}

The effectiveness of authentic assessment instruments in music band learning aims to determine the effectiveness of the instruments implemented in learning, then the value of the ICC (Intraclass Correlation Coefficient) of the authentic assessment instrument in learning band music is calculated using spps 22 .

\subsubsection{Performance assessment}

Results of the effectiveness of the authentic assessment instrument in band music learning shows in Table 3. 
Table 3. Results of Interclass Correlation Coefficient Effectiveness of Authentic Assessment Instruments in Learning Band Music

\begin{tabular}{llcccccc}
\hline & \multicolumn{2}{l}{$\begin{array}{l}\text { Intraclass } \\
\text { Correlation }\end{array}$} & \multicolumn{2}{c}{$95 \%$ Confidence Interval } & \multicolumn{3}{c}{ F Test with True Value 0 } \\
$\begin{array}{l}\text { Single } \\
\text { Measure }\end{array}$ & B & $\begin{array}{l}\text { Lower } \\
\text { Bound }\end{array}$ & $\begin{array}{c}\text { Upper } \\
\text { Bound }\end{array}$ & Value & df1 & df2 & Sig \\
$\mathrm{S}$ & $.354 \mathrm{a}$ & .421 & .719 & & & & \\
$\begin{array}{l}\text { Average } \\
\text { Measure }\end{array}$ & $.834 \mathrm{c}$ & .687 & .842 & 5,145 & & 43 & .000 \\
$\mathrm{~s}$ & & & & & 14 & 43 & .000 \\
\hline
\end{tabular}

Based on the results of the effectiveness of the authentic assessment instrument in band music learning shows that the instrument is effectively used, very practical and easy to use to be understood by the teacher. The results of this effectiveness test were found to be 0.851 included in the highly effective.

\subsubsection{Project Assessment}

Results of the Interclass Correlation coefficient Effectiveness of Authentic Band Music Instrument Assessments shows in Table 4.

Table 4. Results of The Interclass Correlation Coefficient Effectiveness of Authentic Band Music Instrument Assessments

\begin{tabular}{|c|c|c|c|c|c|c|c|}
\hline \multirow[b]{2}{*}{$\begin{array}{l}\text { Single } \\
\text { Measures }\end{array}$} & \multirow{2}{*}{$\begin{array}{l}\text { Intraclass } \\
\text { Correlation B }\end{array}$} & \multicolumn{3}{|c|}{ 95\% Confidence Interval } & \multicolumn{3}{|c|}{$\begin{array}{c}\text { F Test with True } \\
\text { Value } 0\end{array}$} \\
\hline & & $\begin{array}{l}\text { Lower } \\
\text { Bound }\end{array}$ & $\begin{array}{l}\text { Upper } \\
\text { Bound }\end{array}$ & Value & df1 & $\mathrm{df} 2$ & Sig \\
\hline \multirow{2}{*}{$\begin{array}{l}\text { Average } \\
\text { Measures }\end{array}$} & $.354 \mathrm{a}$ & .421 & .719 & 5,145 & 14 & 43 & .00 \\
\hline & $.834 \mathrm{c}$ & .687 & .842 & 5,125 & 14 & 43 & $\begin{array}{l}.00 \\
0\end{array}$ \\
\hline
\end{tabular}

Based on the results of the effectiveness of project assessment, an average value of 0.834 is obtained and the category is very effective. Thus it can be concluded that this instrument is appropriate to use.

\subsubsection{Written Test Assessment}

Results of the Interclass Correlation coefficient Written Test Rating shows in table 5.

Table 5. Results of The Interclass Correlation Coefficient Written Test Rating

\begin{tabular}{llllllll}
\hline & Intraclass & \multicolumn{3}{c}{$95 \%$ Confidence } & \multicolumn{3}{c}{ F Test with True Value 0 } \\
& Correlation & Lower & Upper & Value & df1 & df2 & Sig \\
Single & B & Bound & Bound & & & & \\
\hline
\end{tabular}




\begin{tabular}{lccccccc}
\hline Measure & & & & & & \\
$\mathrm{s}$ & $.416 \mathrm{a}$ & .301 & .585 & 5,762 & 30 & 180 & .000 \\
$\begin{array}{l}\text { Average } \\
\text { Measure } \\
\mathrm{s}\end{array}$ & $.791 \mathrm{c}$ & 672 & .842 & 5,762 & 30 & 180 & .000 \\
\hline
\end{tabular}

Based on the results of the effectiveness of written test assessment obtained an average value with a percentage of 0.791 and categorized as effective. Thus it can be concluded that this instrument is appropriate to use.

\subsubsection{Portfolio assessment}

Results of the Interclass Correlation coefficient Intraclass Correlation Coefficient Portfolio Assessment shows in Table 6.

Table 6. Results of The Interclass Correlation Coefficient Intraclass Correlation Coefficient Portfolio Assessment

\begin{tabular}{|c|c|c|c|c|c|c|c|}
\hline \multirow[b]{2}{*}{$\begin{array}{l}\text { Single } \\
\text { Measure }\end{array}$} & \multirow{2}{*}{$\begin{array}{l}\text { Intraclass } \\
\text { Correlation } \\
\text { B }\end{array}$} & \multicolumn{2}{|c|}{$95 \%$ Confidence Interval } & \multicolumn{4}{|c|}{ F Test with True Value 0} \\
\hline & & $\begin{array}{l}\text { Lower } \\
\text { Bound }\end{array}$ & $\begin{array}{l}\text { Upper } \\
\text { Bound }\end{array}$ & Value & df1 & df 2 & Sig \\
\hline $\mathrm{s}$ & $.326 \mathrm{a}$ & .301 & .585 & 5,762 & 30 & 180 & $\begin{array}{l}.00 \\
0\end{array}$ \\
\hline $\begin{array}{l}\text { Average } \\
\text { Measure } \\
\text { S }\end{array}$ & $.802 \mathrm{c}$ & 672 & .842 & 5,762 & 30 & 180 & $\begin{array}{l}.00 \\
0\end{array}$ \\
\hline
\end{tabular}

Based on the results of effectiveness assessment of portfolio results obtained an average value with a percentage of 0.802 and categorized as very effective. Thus it can be concluded that this instrument is appropriate to use.

\subsubsection{Product Rating}

Results of the Interclass Correlation coefficient Product Rating Intraclass Correlation Coefficient shows in Table 7

Table 7. Results of The Interclass Correlation Coefficient Product Rating Intraclass Correlation Coefficient

\begin{tabular}{|c|c|c|c|c|c|c|c|}
\hline \multirow{4}{*}{$\begin{array}{l}\text { Single } \\
\text { Measure } \\
\mathrm{s}\end{array}$} & \multirow{2}{*}{$\begin{array}{c}\text { Intraclas } \\
\text { s } \\
\text { Correlat } \\
\text { ion B }\end{array}$} & \multicolumn{2}{|c|}{$\begin{array}{l}\text { 95\% Confidence } \\
\text { Interval }\end{array}$} & \multicolumn{4}{|c|}{ F Test with True Value 0} \\
\hline & & Lower & Upper & Value & $\mathrm{dfl}$ & $\mathrm{df} 2$ & Sig \\
\hline & & Bound & Bound & & & & \\
\hline & $.426 a$ & .301 & .585 & 5,762 & 30 & 180 & .000 \\
\hline $\begin{array}{l}\text { Average } \\
\text { Measure } \\
\mathrm{s}\end{array}$ & $.863 \mathrm{c}$ & 672 & .842 & 5,762 & 30 & 180 & 000 \\
\hline
\end{tabular}


Based on the results of the effectiveness of product valuation obtained an average value with a percentage of 0.863 and categorized as very effective. Thus it can be concluded that this instrument is appropriate to use.

Thus, it can be concluded the effective value of authentic assessment instrument products in the learning of Music Band as shown in Table 8 below.

Table 8. Tabulation of The Value of The Interclass Correlation Coefficient The Effectiveness of The Authentic Assessment Instrument in The Learning Of Band Music

\begin{tabular}{lccc}
\hline \multicolumn{1}{c}{ Product } & Total number of teachers & Interne Correlation Cofecition & Category \\
$\begin{array}{l}\text { The } \\
\text { performa }\end{array}$ & 5 & 81.5 & Very effective \\
nce & & & \\
Project & 5 & 83.4 & Very effective \\
Fortopoli & 5 & 80.2 & Very effective \\
o & & & \\
Article & 5 & 79.1 & Effective \\
Product & 5 & 86.3 & Effective \\
Average & 5 & 82.1 & Very effective \\
\hline
\end{tabular}

Note: the assessments form collected to google classroom.

Based on the SPSS calculation results in Table 8 above, it is known that the product development of authentic assessment instruments in learning Music Bands has an ICC score of 82.1 and is classified as very effective.

The development of authentic assessment instruments in the band's music learning has been effective because it is in accordance with the objectives of being easily implemented, more systematic, and able to see grades quickly and precisely during performance, project, written and portfolio tests. The comparison between instruments before development and after looks very much different. Right on target and in accordance with the objectives. This is consistent with what [3] said which explains the indicators of effective is doing the right job. [5], [12] emphasizes that indicators of effectiveness are the achievement of objectives or in accordance with the objectives. In connection with this [6], [11] explain what shows that effectiveness can be seen from the systemic so that goals can be achieved.

For the effectiveness of the authentic assessment instrument, it was found that the instrument was very effectively used by teachers and students. From the results of the performance assessment, project assessment, written assessment, and portfolio assessment, the product assessment is obtained on average the product development of authentic assessment instruments in learning Music Bands has an ICC score of 82.1 and is classified as very effective.

This shows that the ability of students included in the category of very effective. This is also consistent with the results of [4] which found that authentic assessment instruments were effectively used in learning English in high school. Although with different content, the results of this study also show the same thing with the development of authentic assessment instrument development models in band music learning. The position of assessment is very important in learning band music. The aim is to find out whether a material or curriculum has been mastered by students or not. To find out whether or not the objectives of the component components have been achieved in the form of performance, project, written, and portfolio tasks. The results of this calculation or value become a benchmark (passing grade) to 
determine the effectiveness or failure of the instrument that has been developed. If the value obtained is good or very good means the instrument is effective, and vice versa if the value obtained is not good or in the low category means no effect. Assessment is an activity carried out by the teacher to obtain information objectively, continuously and thoroughly about the process and learning outcomes achieved by students, the results of which are used as a basis for determining subsequent treatment [8]. [10], who emphasizes authentic assessment of specific skills and competencies, to apply skills and knowledge already mastered. Google classroom is very supportive of the implementation of authentic assessment that utilize computer science during a pandemic.

\section{Conclusion}

Based on the objectives, results and discussion of the research described, the following conclusions can be concluded:

1. Has been produced Authentic Instrument Assessment Model in Band Music Learning through the ADDIE development model used google classroom.

2. The Authentic Assessment Instrument Model in Band Music Learning has a level:

a. The validity of authentic assessment instruments in learning band music is 78.82 and is classified as valid.

b. The practicality of the authentic assessment instruments in learning band music is 81.56 and is classified as very practical.

c. The effectiveness of authentic assessment instruments in learning band music is 82.1 and is classified as very effective.

\section{References}

[1] Djemari, Mardapi. 2008. Technique of Preparing test and non-test Instrument. Yogyakarta;Mitra Cendekia Press

[2] Djiwandono, PI. 2016. Characters Education in Content Courses: Self-Scoring as a Means for Developing Honesty in Students. TEFLIN Journal (Online). Vol. 27, No. 2. (http://dx.doi.org/10.15639/teflinjournal.v27i2/153-165).

[3] Drucker, Peter.F. 1999. Management; Duties, Responsibilities, and Practice. Jakarta; Gramedia

[4] Farisi, MI 2012. "Development of Student Self-Assessment as a Model of Assessment and Character Development". National Scientific Conference "Assessment and Building Nation Character" HEPI UNESA 2012 (68-77)

[5] Handoko, T. Hani. 2010. Personalia Management \& Human Resources. BPEEYogyakarta.

[6] Kamarudin, MY, Yusoff, NMRN, Ahmad, HY, \& Ghani, KA 2016. Inculculation of Higher Order Thinking Skills (HOTS) in Arabic Language Teaching at Malaysian Primary School. Scientific Research Publishing, (Online), Vol. 6, (http://dx.doi.org/10.4236/ce.2016.72030).

[7] Mertasari, MNS, Yu \& a, M. \& Gita, N. 2017. "Event Based Assessment: A Formative Assessment of Integrated Character Education". Advance in Social Science, Education 
and Humanities Research (ASSEHR), (Online), Vol. 134, (http: // doi: 10.2991 / icirad$\underline{17,247.34 /) \text {. }}$

[8] Ministry of Education and Culture Directorate of Middle School Development Directorate General of Primary and Secondary Education. 2015. Assessment Guidelines for Middle School (SMP).

[9] Nitko, A.J. 2001. Educational Assessment of Students (3rd ed.). New Jersey: Merrill Prentice Hall.

[10] Stiggins, Richard J .1997. Student-centered Clasroom Assesment. Michigan University, Merrill

[11] Steers, Richard.M. (1985). Organizational Effectiveness of the Periode Practice (Interpreting. Magdalene). Jakarta: Erlangga.

[12] Ugur, H. 2015. Self-Awareness and Personal Growth: Theory and Application of Bloom's Taxonomy. Eurasian Journal of Educational Research, (Online), Vol. 60, No. 6,(http://doi.org/10.14689/ejer.2015.60.6) 